\title{
The Impact of Tourism on Economic Growth: A Panel Co-integration from the Community of Portuguese-speaking Countries (CPLP)
}

\author{
Ladson Pires Andrade \\ Hunan University, Changsha, Hunan Province, P. R. China \\ E-mail: tinteira@hotmail.com \\ Hassane Mahamad Velonjara \\ Hunan University, Changsha, Hunan Province, P. R. China \\ E-mail: hvelonjara@outlook.com
}

Received: July 18, 2020 Accepted: August 17, 2020 Published: August 24, 2020

doi:10.5296/ber.v10i3.17361ＵRL: https://doi.org/10.5296/ber.v10i3.17361

\begin{abstract}
This article aims to examine the impact of tourism on economic growth, a panel co-integration from a community of Portuguese-speaking countries (CPLP). Being one of the leading sectors for economic development for most of the transaction economies, which helps bring down the unemployment rate, bring more foreign currency into the local economy, etc. Therefore, tourism is indispensable for GDP growth for any country; Thus, most of the leaders want to design the best policies as possible to boost this sector. So, the CPLP countries are not left behind when coming to an incentive more and more tourism. This work employs a Fully modified ordinary least squared (FMOLS) and dynamic ordinary least squared (DOLS) and a co-integration technique to test whether there's a long-term association between expenditure on tourism and growth from 2000 to 2016. The FMOLS and DOLS outcomes show that travelers' spending exerts a great influence on development for these nations and it causes the long-running association between tourism to growth, which provides that tourism exerts a positive influence on GDP. We conclude this article with some policy recommendations.
\end{abstract}

Keywords: Tourism expenditure, Growth, Co-integration technique, Portuguese-speaking nation-states 


\section{Introduction}

Tourism is viewed as the main cause of economic expansion specifically for $\mathrm{r}$ nations that don't have many natural resources or simply saying developing and transaction economies. A reported of World Travel and Tourism Council (WTTC, 2018) shows that the value of tourism to growth is universally recognized, creating on average 300 million jobs yearly and supporting one in of ten jobs globally, making it a dynamic engine of job opportunity and generating an approximately $11 \%$ of global GDP. Tourism as service exports can help states to sustain their economic progress, reduce unemployment (Christie et al., 2014). Another status of tourism activity, it helps nations to equilibrate their balance of payment and producing a high worth of overseas currency receipts; this contributes to the supportable progress of transition economies. Recently attention has been drawn to tourism as a key factor of growth activities for many nations. Thus, nation-states set out to attract tourism by building new infrastructures such as hotels, resorts, and airports, and by implementing policies to facilitate the inflow of tourism.

This work is intended to examine the effect of tourism on economic growth by using physical capital and export as control variables in five selected Portuguese-speaking nations: Angola, Brazil, Cape Verde, Mozambique, and Portugal.

\subsection{Overview of "Portuguese Empire” or Colonialism Era}

To get a better idea of the concept "Portuguese-speaking states", first, we have to understand the Portuguese Empire or Portuguese Colonial Empire (period of colonization) that began in the 15 th century with the navigation to discover the world. As a poor state and with fewer demographic resources compared to other European states, they consequently decided to navigate around the world to become richer. The idea was to plant business outposts along with the seaboard to establish allies and contact local populations. The empire started taking its initial shape in the 15th century, and its development can be segmented into three major historical periods: from the beginning of colonization until the late 19th century; from the early 20th century until the end of World War II; and from the 1950s to the independence of the Portuguese-speaking African countries. A system of exchange of goods and people was created through an intricate business network: The trade of slaves from Africa to Brazil; the sugar business from Brazil to Europe; spices from India to Europe; and the export of artifacts from Europe to all the above regions. From the 15th century, the empire's leader paid more attention to the consolidation of cultural and linguistic factors, based on the shipping trade, between Europe, Africa, Asia, and South America (Brazil).

It is worth recalling that the "Portuguese Empire" spanned the globe: the mainland and its adjacent regions - Angola, Cape Verde, Guinea-Bissau, Mozambique, Sao Tome, Brazil, "Portuguese India", Macau and East-Timor). Boxer and Hartwell (1973), argued that empire enlargement, culture, and language were introduced by the religions, central leaders, and later by institutions; the contexts of political, religious, and economic enlargement were hindered by the progress of Portugal and its colonies. In his book - "Unpacking Cosmopolitanism for the Social Sciences", Beck (2006) stated that the mobility of people, products, and views across these lands, and the idea of an "an imperial state" were greatly stressed before the 
emergence of the press, which was limited by the Inquisition and the authoritarian power of the Crown. The idea of an "empire state" had a two-fold press impact, according to Anderson (2006), the idea of "Lusophone space" or simply Portuguese-speaking states, yet it allowed a greater vividness than language or even culture alone, which created the base for independence, such as that of Brazil in 1822.

\subsection{Post-colonial Period}

The post-colonial period consisted of the independence of these former colonies of the so-called "Portuguese Empire". Up till then, to date, the relation between Portugal and its former colonies was very good, due to the language and cultural background of these Portuguese-speaking states. Migratory systems can be identified from different patterns such as the exchange of migrants among states, (Kritz and Zlotink -1992). The authors noted that the system migration was based on many aspects such as, social, economic, demographic, and political, it infers different ties: family connections, recruitment of the labor force, and exploitation. Similarly, to other European colonizers, Portugal found its place in many migration systems, one of which was the "Lusophone migration system", (Baganha 2009). Two other factors are important in terms of characterizing the post-colonial "Lusophone migration system": firstly, the cultural aspect that connected these states, and secondly, bilateral ties, which made the peoples more connected.

During the 16th and 19th centuries, there were approximately three and a half (3.5) million African slaves went to Brazil, (Nunes 2003). The author argued that Brazil obtained more migrants from its colonizer, only when it became independent. On the other hand, during the 16th to 18th centuries, approximately five hundred thousand slaves were brought to the colonizer territory from its external territories, (Tinhorão 1988). However, after sovereignty was granted to these external territories, the number of migrants that came to Portugal increased substantially. This shows how the Portuguese-speaking states worked closely together even after each state became free from the colonizer. Cultural and language factors played a key role in this interaction.

\section{Literature Review}

Recently, empirical research has been conducted to investigate what's the impact of tourism on economic growth in different states/regions. Due to the importance of the tourism industry, many governments have engaged in promoting tourism expansion to boost national growth, which reduces the unemployment rate. Also, it helps to improve external earnings currency exchange and promoting the improvement of infrastructures (Nowak \& Sahli, 2007). An empirical study on tourism-led growth evidence from India, conducted by Nitasha Sharma (2018), showed that there's a long-term association between tourism and GDP, and she concluded that tourism receipts support growth in India. As Seghir et al.'s (2015) noted in tourism spending-economic growth causality in 49 states by using a dynamic panel data approach; their findings showed a long-running association between tourism spending and growth.

Salifou \& Haq (2017) analyzed tourism, globalization, and growth by using a panel 
co-integration for some selected West African states, and according to their co-integration test, they got to the conclusion that in the long-term exists a positive effect among tourism, growth, physical capital, globalization, and FDI. Furthermore, they stated that the tourism sector is a very important source of growth in the region. The research carried out by Gunduz \& Hatemi-J, (2005) on Turkey's case showed that tourism activity leads to growth, and the authors found unidirectional causality running from tourism receipts to growth. This means that tourism receipts contribute to GDP growth in Turkey and, it is one of the key components of economic growth. Also, Brida \& Giuliany (2012) also found unidirectional causality running from tourism to growth. Many other scholars found a unidirectional causality from tourism expenditure to economic development: Akimboade \& Braimoh (2010) for South Africa, Narayan et al., (2010) for the pacific islands mainly Fiji, Tonga, Salomon Islands, and Papua New Guinea.

Despite the unidirectional causality from tourism to growth, many researchers have found a bidirectional causality running from tourism to economic expansion, Ongan \& Demiroz (2005) for Taiwan case; Lee et al., (2008) and Dritsakis (2004) for non-OECD nations and Greece respectively; Tang (2011) for the tourism-led growth nexus Malaysia; A similar outcome was found by Samimi A. J. et al., (2011) in the study of tourism and growth in emerging states (P-VAR approach). As Ertugrul et al., (2015) noted, tourism positively impacts growth in an empirical investigation between growth and tourism by using a co-integration test. Tourism activity would produce a rise in income at least two ways: first, tourism enhances effectiveness through rising competition among corporations in the receptor country and other global tourist purposes. Secondly, it facilitates the utilization of economies of scale in national companies.

The direct and indirect effect of travelers' expenditure stimulates further activities in the economy (Spurr, 2006). This simply means that a rise in travelers' expenditure leads to other activities in associated businesses, and the general linkage with them will be greater than the early outflow. Yet it is difficult to account for these paybacks to the economy, given the varied nature of this activity.

Travelers' spending can be an export option, providing the external exchange's earnings to recipient states; then, it will use them to buy goods and services, which boosts growth on the recipient state. Instead, the economic expansion also provides a vital reason for the expansion of tourism. Growth can help tourism activities through the upgrading of infrastructure and other facilities. The comparative cost of non-traded goods would be raised by the growth in the number of travelers, expanding the tertiary sector, and yielding a gain in revenues. Then, if the value of non-traded goods value rises, it results in a lowering of demand for the assets used in the traded sector; consequently, the business progress in the traded goods may lower the welfare of residents, (Chao et al., 2009). Fayissa et al., (2008) argued that intercontinental travelers have a positive influence on the development of Sub-Saharan African nations: a rise in $10 \%$ in travel spending boosts the regions' economies by $0.4 \%$ per capita income, and thus tourism leads to growth. Sakai (2009) argued that physical capital is essential for infrastructures such as airports, harbors, roads, etc. which are the key drivers of the expansion. Yet the improvement of infrastructure is essential, predominantly for unindustrialized nations 
to compete with another nation-state in attracting tourism.

An empirical study of a Dutch Disease effect in tourism-dependent nations over the long-term was analyzed by Holzner (2011), in which he used data of 134 nations from 1970 2007. Aa panel framework was used in growth per capita that allowed control of reverse causality, non-linear and interactive effects in the long-term. The effects of the Beach Disease effect were not found. On the contrary, it states that, depending on tourism activity as an engine of growth, it does not face real exchange rate distortion and deindustrialization, but these states also experience greater growth rates than normal. Chou (2013) of tourism expansion endorses growth in transaction nations in a panel data analysis of 10 nations. He found the evidence on causality and consistency with the neutral hypothesis for three of these 10 nations on the study (Bulgaria, Romani, and Slovenia); the theory of growth held for three (Cyprus, Latvia, and Slovakia), with an inverse association for the Czech Republic and Poland. lastly, for Estonia and Hungary, the feedback theory was held. Kuang, Tzu \& Tsai (2016) studied the effect of travel on growth by using a quantile regression test; their findings endorsed that tourism affects growth at the top end of the distribution ( 0.3 to 0.9 quantiles) of growth in Taiwan. But tourism expansion had an insignificant influence on growth at the low end of the distribution ( 0.1 to 0.2 quantiles) of growth in Taiwan. Further, Abdulkarim K. Alhowaish (2016) studied the leisure industry expansion of a sustainable economic development strategy using long-term evidence from Gulf Cooperation Council (GCC) nations with a panel series from 1995 to 2012. His analysis was as an individual and as the whole case: an overall unidirectional causality moved from growth to expansion of tourism. Moreover, republics like Kuwait, Saudi Arabia, Qatar, and the United Arab Emirates showed growth-led tourism theory. The inverse theory occurred for Bahrain, whereas for Oman there was no association between tourism and growth.

Therefore, based on the literature, up to date there's no conclusive finding on this topic whether tourism has a positive or negative influence on GDP growth. Thus, according to our best knowledge, no research has been carried on this matter on the Portuguese-speaking countries (CPLP), to assess what's the effect between travelers' expenditure and growth. This is the first research to be conducted for some of the selected Portuguese-speaking nations. By using a Pedroni co-integration test, it allows us to study the long-run relationship among the variables, therefore, we use the fully modified ordinary least squared (FMOLS) and dynamic ordinary least squared (DOLS) approach.

\section{Data, Methodology and Model Specification}

This empirical study employed yearly data on 5 selected Portuguese speaking nations-Angola, Brazil, Cape Verde, Mozambique, and Portugal-from the period 2000 to 2016. The variables used in this research include the real gross domestic product, tourism expenditure, physical capital, and export. Variables are expressed in current price (USD) and World Bank Indicators (WBI) and were the source of our variables. The choice of the variables was decided from the literature studied and presented. 


\subsection{Methodology and Model Specification}

The choice of a suitable method is a vital aspect to analyze the long-running association in panel data. The co-integration test is typically one of the most suitable approaches for studying the long-term association between variables. The approach applied in this article was divided into different parts. Firstly, we perform LLC and IPS unit root test of the series; Secondly, when series was integrated in the same order, the Pedroni co-integration test was applied; finally, FMOLS and DOLS were applied when series was co-integrated.

Phillips \& Hansen (1990) developed the FMOLS, but a decade later it was modified by Pedroni (2000), which makes it more adequate for panel series analysis to check the long-running association between variables in the regression. The FMOLS technique retrieves the unbiased estimators of co-integration regression underneath a single baseline equation. This allows us to remove any endogeneity bias problem. Furthermore, it discourses on potential autocorrelation issues, and its estimator is asymptotically unbiased and entirely efficient in the attendance of assorted regular asymptotes.

Saikkonen (1991) and Stock \& Watson (1993) introduced a dynamic ordinary least square, but the former was called Saikkonen's dynamic ordinary least squares, which later changed to DOLS. These two methods are more efficient and consistent for the co-integration vector which is free from bias and serial correlation.

Following the analysis of some empirical research, our model is defined as follows:

$$
\mathrm{GDP}=f(\mathrm{TEXP}, \mathrm{K}, \mathrm{EXP})
$$

Where RGDP refers to a real gross domestic product, TEXP represents the tourism expenditure, $\mathrm{K}$, means physical capital and EXP represents export.

To find the long-term association among variables and to better interpret the outcomes as elasticities, the logarithm form has been applied to the equation, which then shows as equation 2 below:

$$
\mathrm{LGDP}=\beta_{0}+\beta_{1} \text { LTEXP }_{\mathrm{it}}+\beta_{2} \mathrm{LK}_{\mathrm{it}}+\beta_{3} \operatorname{LogEXP}_{\mathrm{it}}+\mu_{\mathrm{it}}
$$

\section{Interpretation of Empirical Results}

Levin, Lin \& Chu (2002) and Im, Pesaran \& Shin's stationarity test (2003), was employed to avoid spurious of estimation. Variables were at a non-stationary at level, then we converted them into first difference and they become free of stationarity. Either LLC and IPS stationarity tests took as reference the Augmented Dickey-Fuller specification as follows.

$$
\Delta y_{i, t}=\rho_{i} y_{i, t-1} \sum_{j=1}^{\rho_{i}} \delta_{i, j} \Delta y_{i, t-1 j}+\varepsilon_{i, t}
$$

The LLC test took the parameters $\left(\rho_{i}\right)$ as persistent and its was presumed to be similar in the panel series (i.e., $\rho_{i}=\rho$ for all (i), and the lag order $\left(\rho_{i}\right)$ might easily differ. the null hypothesis of this test, $\mathrm{H}_{0}=\rho_{\mathrm{i}}=0$ for all (i), contrary to the alternative $\mathrm{H}_{0}<\rho_{\mathrm{i}}=0$ for all (i). if the null hypothesis was rejected, then the panel might have a co-integration. while 
the IPS test was different by assuming $\left(\rho_{\mathrm{i}}\right)$ to be heterogeneous in the panel. the null hypothesis of IPS suggested $\mathrm{H}_{0}=\rho_{\mathrm{i}}=0$ for all (i) in contradiction to alternative $\mathrm{H}_{0}<\rho_{\mathrm{i}}=0$ for all (i). Again, if the null hypothesis was rejected, then the series might be co-integrated. Table 1 shows the results of the unit root test employed in our study after the first difference series was free of non-stationarity.

Table 1. Unit root tests

\begin{tabular}{|l|l|l|l|l|l|}
\hline \multicolumn{2}{|l|}{ Methods } & \multicolumn{2}{l|}{ Levin, Lin \& Chu (LLC) } & \multicolumn{2}{l|}{ Im, Pesaran \& Shin (IPS) } \\
\hline Variables & & Constant & Constant \& trend & Constant & Constant \& trend \\
\hline Level & LGDP & -0.17131 & -0.13925 & $-2.5532^{* * *}$ & -0.7002 \\
\hline & LTEXP & -0.13769 & -0.25288 & -1.5279 & -1.2338 \\
\hline & LK & -0.19079 & -0.18493 & -2.0104 & -0.9225 \\
\hline & LEXP & -0.17967 & -0.14031 & $-2.3369^{* *}$ & -0.5821 \\
\hline Fist & $\Delta$ LGDP & -0.69128 & $-1.27129 * * *$ & -1.7748 & $-3.3887 * * *$ \\
\hline Difference & DLTEXP & -0.80549 & $-1.02329 * *$ & -2.1317 & $-2.8768^{* *}$ \\
\hline & DLK & -0.71148 & $-1.14532^{* *}$ & -1.7273 & $-2.7519^{* *}$ \\
\hline & DLEXP & -0.81366 & $-1.49330^{* * *}$ & -1.9538 & $-3.5273^{* * *}$ \\
\hline
\end{tabular}

Source: author's computation using Eviews; ${ }^{* *},{ }^{* *}$ statistical significance at $1 \%$ and $5 \%$ respectively; $\Delta$ represents the first difference

To run the long-term regression in the panel series it was necessary to apply a co-integration test. Our research employed the Pedroni (1999) co-integration test, and results showed that variables were co-integrated which is the main criterion to selected the FMOLS and DOLS method. Table 2 demonstrates that four out of seven tests were very significant; consequently, co-integration existed between variables used in the study.

Table 2. Pedroni co-integration test

\begin{tabular}{|l|l|l|}
\hline Test & Statistic & Prob. \\
\hline (Within dimensions) & & \\
\hline Panel v-Statistic & 1.128667 & 0.1295 \\
\hline Panel rho-Statistic & 0.829600 & 0.7966 \\
\hline Panel PP-Statistic & -2.124234 & $0.0168 * * *$ \\
\hline Panel ADF-Statistic & -1.931582 & $0.0267 * * *$ \\
\hline (Between dimensions) & & \\
\hline Group rho-Statistic & 1.572621 & 0.9421 \\
\hline Group PP-Statistic & -3.538055 & $0.0002 * * *$ \\
\hline Group ADF-Statistic & -2.528110 & $0.0057 * * *$ \\
\hline
\end{tabular}

Source: author's computation using Eviews; ***, refers to statistical significance at $1 \%$ level. 
The next table presents the estimation outcomes of the FMOLS and DOLS, showing a long-term association of regressors to the predicted variable.

Table 3. Estimation results of the fully modified OLS and dynamic OLS

\begin{tabular}{|l|l|l|}
\hline Variables & FMOLS & DOLS \\
\hline LTEXP & $0.153337 * * *(2.799899)$ & $0.159418^{* *}(1.998486)$ \\
\hline LK & $0.451890 * * *(13.52266)$ & $0.465603 * * *(2.578106)$ \\
\hline LEXP & $0.468506 * * *(10.58991)$ & $0.446189 * * *(3.049708)$ \\
\hline$R^{2}$ & 0.987 & 0.997 \\
\hline Adj. $R^{2}$ & 0.987 & 0.992 \\
\hline
\end{tabular}

Source: author's computation using Eviews; t-stat is in brackets; $* * * * *$ significant at $1 \%$, and $5 \%$ level respectively.

From the table above, both methods showed a similar outcome with a positive coefficient and significance. For instance, our main variable in this study, which is the tourism receipt is positively significant for the growth of these selected countries in our study. In another word, it means that in long term tourism service is very important for the CPLP countries. The findings are similar to Brida \& Giuliany (2012), Ertugrul et al., (2016). This means that a one percent rise in tourism expenditure boosted the growth of these nations by fifteen percent in GDP. This proves that tourism leads to growth for these five Portuguese-speaking nations in the study, while the physical capital positively influenced growth. In other words, a one percent increase in physical capital exerted a forty-five percent rise in GDP.

The export factor also presented a very significant impact on growth with its positive coefficient, showing that one percent up in exports, raising the GDP by forty-six percent; similar outcomes were obtained by Spurr (2009).

\section{Conclusion and Policy Implications}

This research empirically investigates the effect of tourism on growth for some selected Portuguese-speaking nations mainly-Angola, Brazil, Cape Verde, Mozambique, and Portugalby using a panel co-integration test. Our empirical findings suggested that there's a positive effect of tourism on GDP in the CPLP. Further, the long-term association between tourism expenditure, physical capital, and exports leading to growth was confirmed by the FMOLS and DOLS technique. Our findings are consistent with studies, such as those of - Brida \& Giuliani (2012), Ertugrul et al., (2017), Tang (2011), Spurr (2009), Seghir, et al., (2015), Gunduz \& Hatemi-J, (2005).

The following are some policy suggestions derived from the outcome, which could be very important for policymakers. Firstly, policymakers should design and implement a better growth model, focusing more on internal tourism expansion as a new model of economic enlargement. Secondly, more incentives should be implemented in this sector, such as reducing taxes to the small and medium enterprises, allowing them to offer better incentives to internal travelers, thus creating more employment and consequently boosting growth. 
finally, to get an improved global reputation, strong and efficient security policies should be implemented to attract more tourists.

\section{References}

Anderson, B. (2006). Imagined communities: Reflections on the origin and spread of nationalism. Verso books.

Akinboade, O. A., \& Braimoh, L. A. (2010). International tourism and economic development in South Africa: A Granger causality test. International Journal of Tourism Research, 12(2), 149-163. https://doi.org/10.1002/jtr.743

Alhowaish, A. K. (2016). Is tourism development a sustainable economic growth strategy in the long run? Evidence from GCC countries. Sustainability, 8(7), 605.

https://doi.org/10.3390/su8070605

Baganha, M. I. (2009). The Lusophone migratory system: patterns and trends. International Migration, 47(3), 5-20. https://doi.org/10.1111/j.1468-2435.2009.00522.x

Beck, U. (2006). Cosmopolitan vision. Polity.

Boxer, C. R., \& Hartwell, R. M. (1973). The Portuguese seaborne empire, 1415-1825 (pp. 268-74). Penguin Books.

Brida, J. G., \& Giuliani, D. (2013). Empirical Assessment of the Tourism-Led Growth Hypothesis: The Case of the Tirol-Südtirol-Trentino Europaregion. Tourism Economics, 19(4), 745-760. https://doi.org/10.5367/te.2013.0317

Chao, C. C., Hazari, B. R., Laffargue, J. P., \& Yu, E. S. (2009). A dynamic model of tourism, employment and welfare: the case of Hong Kong. Pacific Economic Review, 14(2), 232-245. https://doi.org/10.1111/j.1468-0106.2009.00441.x

Chou, M. C. (2013). Does tourism development promote economic growth in transition countries? A panel data analysis. Economic Modelling, 33, 226-232.

https://doi.org/10.1016/j.econmod.2013.04.024

Christie, I., Fernandes, E., Messerli, H., \& Twining-Ward, L. (2014). Tourism in Africa: Harnessing tourism for growth and improved livelihoods. The World Bank. https://doi.org/10.1596/978-1-4648-0190-7

Dritsakis, N. (2004). Cointegration analysis of German and British tourism demand for Greece. Tourism management, 25(1), 111-119. https://doi.org/10.1016/S0261-5177(03)00061-X

Ertugrul, H. M., \& Mangir, F. (2015). The tourism-led growth hypothesis: empirical evidence from Turkey. Current Issues in Tourism, 18(7), 633-646.

https://doi.org/10.1080/13683500.2013.868409

Fayissa, B., Nsiah, C., \& Tadasse, B. (2008). Impact of tourism on economic growth and development in Africa. Tourism Economics, 14(4), 807-818. 
https://doi.org/10.5367/000000008786440229

Gunduz*, L., \& Hatemi-J, A. (2005). Is the tourism-led growth hypothesis valid for Turkey?. Applied Economics Letters, 12(8), 499-504. https://doi.org/10.1080/13504850500109865

Holzner, M. (2011). Tourism and economic development: The beach disease? Tourism Management, 32(4), 922-933. https://doi.org/10.1016/j.tourman.2010.08.007

Im, K. S., Pesaran, M. H., \& Shin, Y. (2003). Testing for unit roots in heterogeneous panels. Journal of econometrics, 115(1), 53-74. https://doi.org/10.1016/S0304-4076(03)00092-7

Kuang, T., \& Tsai, Y. F. (2016). The effect of tourism growth on economic growth: A quantile regression analysis. [Online] Available:

https://scholarworks.umass.edu/ttra/2009/Presented_Papers/37

Kritz, M. M., \& Zlotnik, H. (1992). Global interactions: Migration systems, processes, and policies. International migration systems: A global approach, 1-16.

Lee, C. C., \& Chang, C. P. (2008). Tourism development and economic growth: A closer look at panels. Tourism management, 29(1), 180-192.

https://doi.org/10.1016/j.tourman.2007.02.013

Levin, A., Lin, C. F., \& Chu, C. S. J. (2002). Unit root tests in panel data: asymptotic and finite-sample properties. Journal of econometrics, 108(1), 1-24.

https://doi.org/10.1016/S0304- 4076(01)00098-7

Narayan, P. K., Narayan, S., Prasad, A., \& Prasad, B. C. (2010). Tourism and economic growth: a panel data analysis for Pacific Island countries. Tourism economics, 16(1), 169-183. https://doi.org/10.5367/000000010790872006

Nowak, J. J., \& Sahli, M. (2007). Coastal tourism and 'Dutch disease'in a small island economy. Tourism Economics, 13(1), 49-65. https://doi.org/10.5367/000000007779784452

Nunes, R. B. (2003). Um panorama histórico da imigração portuguesa para o Brasil. ARQUIPÉLAGO-Revista da Universidade dos Açores, 173-196.

Demiroz, D. M., \& Ongan, S. (2005). The contribution of tourism to the long-run Turkish economic growth. Ekonomický časopis, 9, 880-894.

Pedroni, P. (1999). Critical values for cointegration tests in heterogeneous panels with multiple regressors. Oxford Bulletin of Economics and statistics, 61(S1), 653-670.

https://doi.org/10.1111/1468-0084.61.s1.14

Pedroni, P. (2000). Fully modified OLS for heterogeneous cointegrated panels. Advances in econometrics, 15, 93-130._https://doi.org/10.1016/S0731-9053(00)15004-2

Phillips, P. C., \& Hansen, B. E. (1990). Statistical inference in instrumental variables regression with I (1) processes. The Review of Economic Studies, 57(1), 99-125.

https://doi.org/10.2307/2297545

Saikkonen, P. (1991). Asymptotically efficient estimation of cointegration regressions. 
Econometric theory, 1-21. https://doi.org/10.1017/S0266466600004217

Sakai, M. (2006). 12 Public sector investment in tourism infrastructure. International handbook on the economics of tourism, 266. https://doi.org/10.4337/9781847201638.00022

Salifou, C. K., \& Haq, I. U. (2017). Tourism, globalization and economic growth: a panel cointegration analysis for selected West African States. Current Issues in Tourism, 20(6), 664-667. https://doi.org/10.1080/13683500.2016.1175421

Samimi, A. J., Sadeghi, S., \& Sadeghi, S. (2011). Tourism and economic growth in developing countries: P-VAR approach. Middle-East Journal of Scientific Research, 10(1), 28-32.

Seghir, G. M., Mostéfa, B., Abbes, S. M., \& Zakarya, G. Y. (2015). Tourism spending-economic growth causality in 49 countries: A dynamic panel data approach. Procedia Economics and Finance, 23(1613-1623).

https://doi.org/10.1016/S2212-5671(15)00402-5

Sharma, N. (2018). Tourism led growth hypothesis: empirical evidence from India. African Journal of Hospitality, Tourism and Leisure, 7(2), 1-11. [Online] Available: https://www.ajhtl.com/uploads/7/1/6/3/7163688/article_7_vol_7_2_2018.pdf

Spurr, R. (2006). Tourism satellite accounts. In L. Dwyer \& P. Forsyth (Eds.), International handbook on the economics of tourism (pp. 283-300), Cheltenham, UK, Edward Elgar. https://doi.org/10.4337/9781847201638.00024

Stock, J. H., \& Watson, M. W. (1993). A simple estimator of cointegrating vectors in higher order integrated systems. Econometrica: Journal of the Econometric Society, 783-820. https://doi.org/10.2307/2951763

Tang, C. F. (2011). Tourism, real output and real effective exchange rate in Malaysia: a view from rolling sub-samples.

Tinhorão, J. R. (1988). Os negros em Portugal: uma presença silenciosa (Vol. 31). Caminho.

WTTC. (2018). [Online] Available:

https://www.wttc.org/-/media/files/reports/economic-impact-research/regions-2018/world201 8.pdf

\section{Copyright Disclaimer}

Copyright for this article is retained by the author(s), with first publication rights granted to the journal.

This is an open-access article distributed under the terms and conditions of the Creative Commons Attribution license (http://creativecommons.org/licenses/by/4.0/). 